\title{
Roles of high-mobility group box 1 in murine experimental colitis
}

\author{
HIROSHI YAMASAKI $^{1}$, KEIICHI MITSUYAMA ${ }^{1}$, JUNYA MASUDA $^{1}$, KOTARO KUWAKI $^{1}$, \\ HIDETOSHI TAKEDATSU ${ }^{1}$, GEN SUGIYAMA ${ }^{1}$, SHINGO YAMADA ${ }^{2}$ and MICHIO SATA ${ }^{1}$
}

\author{
${ }^{1}$ Division of Gastroenterology, Department of Medicine, Kurume University School of Medicine, Asahi-machi 67, \\ Kurume 830-0011; ${ }^{2}$ Central Institute, Shino-Test Corporation, Oonodai 2-29-14, Sagamihara 229-0011, Japan
}

Received January 31, 2008; Accepted October 10, 2008

DOI: $10.3892 / \mathrm{mmr} 00000056$

\begin{abstract}
High-mobility group box 1 (HMGB1) plays a role in inflammatory and immune-mediated diseases. This study investigated the role of HMGB1 in colonic inflammation. Colitis was induced by orally feeding mice $4.5 \%$ dextran sulfate sodium (DSS) for up to 7 days. Mice were sacrificed on days $0,3,7$ and 10 , and the colon harvested for the measurement of HMGB1 and pro-inflammatory cytokines. To block HMGB1 induction, an anti-HMGB1 antibody was administered intraperitoneally $2 \mathrm{~h}$ before or 3 days after the induction of colitis, and disease severity was assessed by clinical and histological scoring. The colonic levels of tumor necrosis factor- $\alpha$ and interleukin- $1 \beta$ were elevated in relation to disease severity. The level of HMGB1 increased more slowly than that of the cytokines. Immunohistochemical study of the colons showed that the tissues of mice treated with DSS had a higher expression of HMGB1 and its receptor - the receptor for advanced glycation end products - than normal controls, especially in inflammatory infiltrates. The antiHMGB1 antibody ameliorated tissue damage. In conclusion, HMGB1 is an important mediator of colonic inflammation, and suppression of this protein partially protects against colonic inflammation.
\end{abstract}

\section{Introduction}

Inflammatory bowel disease (IBD), such as ulcerative colitis or Crohn's disease, is characterized by chronically relapsing inflammation of the bowel involving pro-inflammatory cytokines, chemotactic peptides and arachidonic acid metabolites (1-3). In particular, IBD can be exacerbated by increased secretion of pro-inflammatory cytokines. Consequently, an array of therapeutic approaches targeting pro-inflammatory cytokines, such as tumor necrosis factor (TNF)- $\alpha(4,5)$ or interleukin (IL)-6 $(6,7)$, have been extensively investigated.

Correspondence to: Dr Keiichi Mitsuyama, Division of Gastroenterology, Department of Medicine, Kurume University School of Medicine, Asahi-machi 67, Kurume 830-0011, Japan

E-mail: ibd@med.kurume-u.ac.jp

Key words: high-mobility group box 1 , receptor for advanced glycation end products, experimental colitis, ulcerative colitis, Crohn's disease
High-mobility group box 1 (HMGB1) protein, originally identified as a DNA binding protein, also has potent proinflammatory properties (8-10). Exposure of neutrophils or macrophages to HMGB1 induces the nuclear translocation of NF- $\kappa \mathrm{B}$ and enhances the production of pro-inflammatory cytokines, including TNF- $\alpha$ and IL-1, in part through the receptor for advanced glycation end products (RAGE) (11-13). Systemic administration of recombinant HMGB1 is lethal (14), and the intratracheal injection of HMGB1 results in the development of acute lung injury (15). In contrast, inhibition of HMGB1 activity with anti-HMGB1 antibodies increases survival in mice with endotoxemia (14) or bacterial peritonitis (16) and decreases the severity of acute hepatic injury (17). Together, these data suggest that HMGB1 plays a key role in the development of colonic inflammation.

Oral administration of dextran sulfate sodium (DSS) induces colonic inflammation in mice $(18,19)$. This study aimed to examine whether HMGB1 protein is differentially expressed in DSS-induced colitis in mice and to evaluate the effects of anti-HMGB1 antibodies on this colitis. Our results indicate that HMGB1 contributes to colonic inflammation.

\section{Materials and methods}

Mice. Seven- to 8-week-old female BALB/c mice were purchased from SLC Co. Ltd. (Shizuoka, Japan) and housed in standard wire-mesh cages. The mice were fed laboratory pellet formula and tap water ad libitum. The study was approved by the Animal Research Committee of Kurume University.

Induction of colitis. Colitis was induced by drinking water supplemented with 4.5\% DSS (M.W. 40,000, ICN Biomedicals, Aurora, $\mathrm{OH}$ ) for 7 days. This model has been described in detail elsewhere (18). Control mice received plain drinking water.

Time course study of colitis. The mice were sacrificed before and at 1, 3, 7 and 10 days following DSS initiation. The colon including the cecum was removed, and the length of the colon from the colo-cecal junction to the anal verge was measured. The colon was then rinsed with ice-cold saline and used to determine cytokine and HMGB1 levels. Clinical score and colon length were also ascertained.

Administration of anti-HMGB1. We intraperitoneally injected either a neutralizing polyclonal chicken IgY anti-HMGB1 anti- 


\section{A Clinical score}

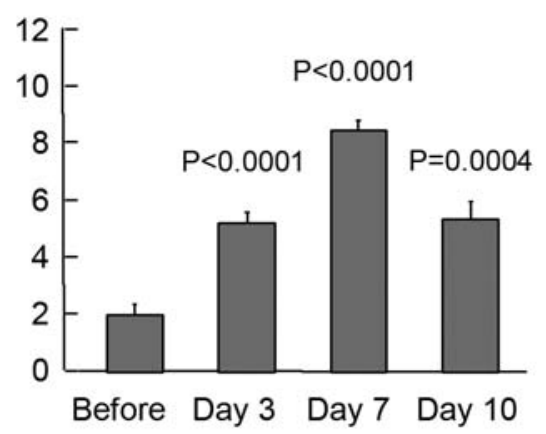

\section{B Colon length $(\mathrm{mm})$}

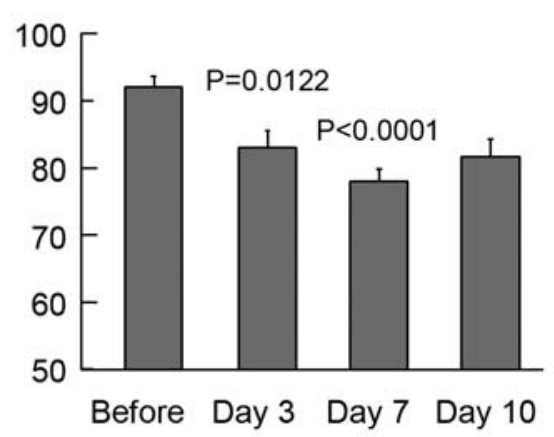

Figure 1. Time courses of (A) clinical score and (B) colon length in mice treated with dextran sulfate sodium (DSS). Mice were sacrificed before and at 3, 7 and 10 days after ingesting $4.5 \%$ DSS. Values are shown as the means \pm SEM for at least 5 mice. Statistical differences vs. control group and p-values vs. normal control mice are shown.

body (200 $\mu \mathrm{g} /$ mouse, Shino-Test, Kanagawa, Japan) or control chicken IgY antibody (200 $\mu \mathrm{g} /$ mouse, Shino-Test) $2 \mathrm{~h}$ before and 3 days after DSS initiation. The mice were sacrificed on day 7 , and colitis severity was assessed according to clinical and histological scores.

Assessment of colitis. Colitis severity was evaluated according to clinical and histological signs, and by colonic length. A clinical score was generated based on a $0-4$ rating of the factors: change in body weight, stool consistency and intestinal bleeding (20). Each variable was given equal weight, with the overall clinical activity score ranging from 0 to 12 . These parameters were measured by an investigator blinded to the treatment group. After randomization, a histological score was assigned by two pathologists who were also group-blinded. The histological score for each segment (cecum, proximal colon, middle colon and distal colon) ranged from 0 to 9 and represented the sum of the scores for the severity of inflammation, damage/necrosis and regeneration. The total histological score ranged from 0 to 12 and consisted of the sum of the score of the distal colon and the score of disease extent (21). We also measured the colonic length from the colo-cecal junction to the anal verge, an established inflam-matory parameter in DSS colitis $(18,22)$.

Organ culture. HMGB1 and cytokine levels in colonic tissue were measured using an organ culture technique as previously described (22). Briefly, tissue samples $3 \mathrm{~mm}$ in diameter were immediately taken from the colon using a dermal punch biopsy instrument (Dispopunch, Stifel Laboratories Ltd., Germany). Three tissue specimens were placed on a metal grid in the wells of a 24-well tissue culture plate (Falcon 3947; BectonDickinson, Lincoln Park, NJ) that contained complete medium consisting of RPMI-1640 (Nissui Pharmaceutical Co. Ltd., Japan), $10 \%$ fetal calf serum, $100 \mathrm{U} / \mathrm{ml}$ penicillin, $100 \mathrm{mg} / \mathrm{ml}$ streptomycin and $2 \mathrm{mM} / \mathrm{l} \mathrm{L}$-glutamine. The specimens were cultured at $37^{\circ} \mathrm{C}$ in $5 \% \mathrm{CO}_{2}$ and $95 \% \mathrm{O}_{2}$. After $24 \mathrm{~h}$, the supernatants were harvested for measurement of HMGB1 and cytokine levels by ELISA.

HMGB1 and cytokine ELISA. ELISA for HMGB1 was performed using monoclonal antibodies to HMGB1 and recombinant HMGB1 as the standard (23). Black polystyrene microtiter plates (Corning, New York, NY) were coated with $100 \mu 1$ anti-HMGB1 polyclonal antibody (peptide antigen: KPDAAKKGVVKAEK) in phosphate-buffered saline (PBS). The unbound antibodies were removed by washing the plate 3 times with PBS containing 0.05\% Tween-20 (washing buffer). The remaining binding sites in the wells were blocked by incubating the plates for $2 \mathrm{~h}$ with $400 \mu \mathrm{l} /$ well PBS-1\% BSA. After washing, $100 \mu 1$ of each dilution of the standard and samples [1:1 dilutions in $0.2 \mathrm{~mol} / 1$ Tris $(\mathrm{pH} 6.5), 0.15 \mathrm{~mol} / 1$ $\mathrm{NaCl}$ containing $1 \% \mathrm{BSA}]$ was added to the wells. The microtiter plates were incubated for $24 \mathrm{~h}$ at room temperature. After washing, $100 \mu \mathrm{l} /$ well of anti-human HMGB1 peroxidaseconjugated monoclonal antibody was added and the plates were incubated at room temperature for $30 \mathrm{~min}$. Followng another washing step, $100 \mu 1$ of lumigen PS-atto was added to each well. Luminescence was measured with a 9000D microplate luminescence reader (Dia-Iatron Co. Ltd., Tokyo, Japan). Immunoreactive TNF- $\alpha$ and IL- $1 \beta$ were quantified in duplicate using commercially available ELISA kits (R\&D Systems, Minneapolis, MN) according to the manufacturer's instructions.

Immunohistochemical analysis. Immunohistochemistry was performed in 5- $\mu \mathrm{m}$ paraffin sections using an avidin-biotin peroxidase procedure (Vector Laboratories, Burlingame, CA). To detect HMGB1 and RAGE, the samples were incubated with primary antibodies (polyclonal rabbit anti-HMGB1 antibody, Shino-test and monoclonal rat anti-RAGE antibody, R\&D Systems). The sections were incubated with biotinylated IgG for $30 \mathrm{~min}$, washed with PBS, incubated with avidin/ biotinylated horseradish peroxidase complex for $1 \mathrm{~h}$ and washed with PBS. Slides were stained with diaminobenzidine tetrahydrochloride substrate for $2 \mathrm{~min}$ at room temperature, rinsed in tap water for $5 \mathrm{~min}$, counterstained with hematoxylin and eosin and dipped in saturated lithium carbonate solution for bluing. Normal blocking serum without primary antibody was used as the negative control.

Statistical analysis. Where appropriate, results are presented as the means \pm SEM. Comparative assessment was performed using the Student's t-test and one-way ANOVA followed by 
A

$\mathrm{IL}-1 \beta(\mathrm{pg} / \mathrm{ml})$

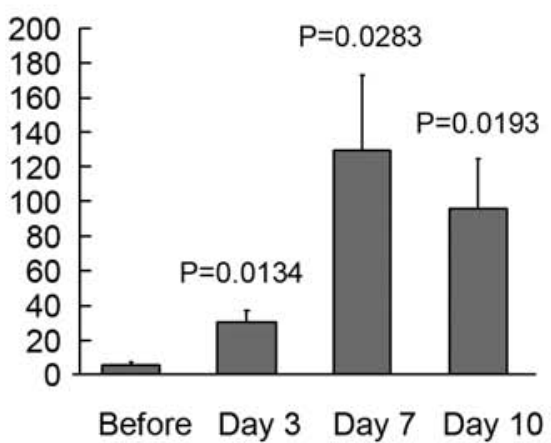

B $\quad$ TNF- $\alpha(\mathrm{pg} / \mathrm{ml})$

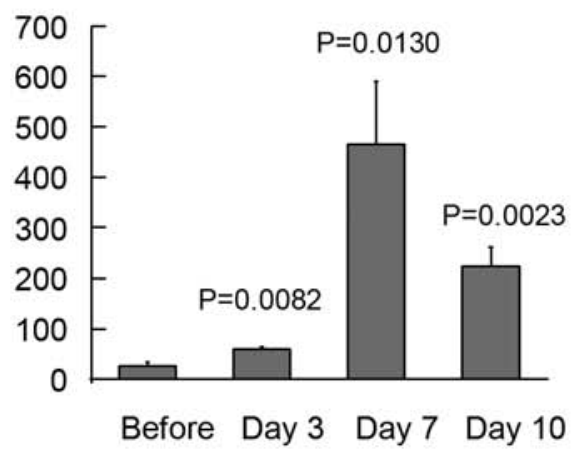

C $\quad$ HMGB1 $(\mathrm{ng} / \mathrm{ml})$

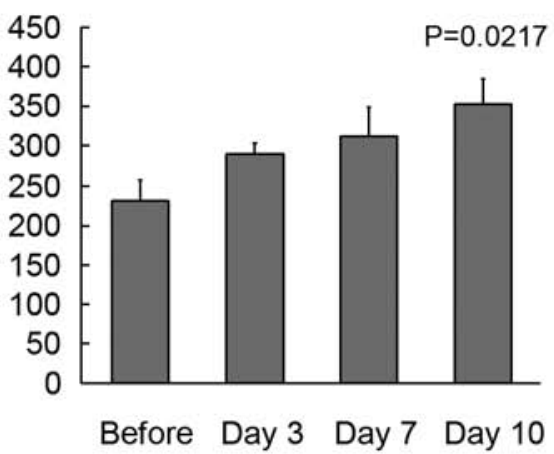

Figure 2. Time courses of colonic levels of (A) IL-1ß, (B) TNF- $\alpha$ and (C) HMBG1 in mice treated with dextran sulfate sodium (DSS). Mice were sacrificed before and at 3,7 and 10 days after ingesting 4.5\% DSS. Levels in organ culture supernatants were determined at designated time points after the ingestion of DSS. Values are shown as the means \pm SEM for at least 5 mice. Statistical differences vs. control group and p-values vs. normal control mice are shown.

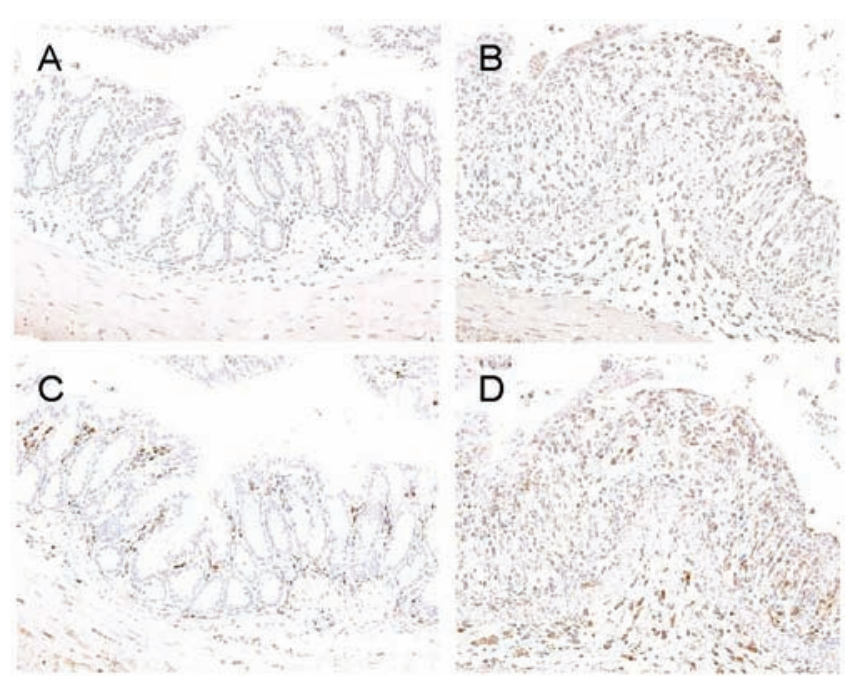

Figure 3. Representative immunohistochemical staining of HMGB1-positive cells in the colonic tissues of (A) normal and (B) DSS mice, and RAGE-positive cells of (C) normal and (D) DSS mice. Colitis was induced by the ingestion of dextran sulfate sodium (DSS) for 10 days. Original magnification, x100.

Scheffe's (post-hoc) test for the statistical significance level of each measured item and score. $\mathrm{P}<0.05$ was considered statistically significant.

\section{Results}

Time course of colonic damage during dextran sulfate sodiuminduced colitis. The ingestion of $4.5 \%$ DSS resulted in severe colon injury as assessed by clinical score and colon length (Fig. 1). These gradually increased, peaked on day 7 and declined thereafter.

Kinetics of cytokine and HMGB1 levels during dextran sulfate sodium-induced colitis. IL-1ß and TNF- $\alpha$ levels began to increase on day 3 , peaked on day 7 and declined thereafter (Fig. 2), in parallel with the degree of colon injury. In contrast, HMGB1 levels peaked on day 10 , after IL-1ß and TNF- $\alpha$, corresponding to the start of injury recovery.
Localization of HMGB1 and receptor for advanced glycation end products in dextran sulfate sodium-induced colitis. Immunohistochemical examination of the colons revealed that tissues from the DSS mice had higher HMGB1 expression than the normal controls, especially in inflammatory infiltrates (Fig. 3A). HMGB1 signal transduction occurs in part through RAGE. Although RAGE staining patterns were similar in normal and DSS colons, the RAGE antigen was more extensively expressed in DSS colons, especially in inflammatory infiltrates and endothelial cells (Fig. 3B).

Role of HMGBI inhibition in dextran sulfate sodium-induced colitis. To determine whether HMGB1 is involved in DSSinduced colitis, we treated mice with anti-HMGB1 antibodies or isotype-specific control antibodies $2 \mathrm{~h}$ before and 3 days after the ingestion of DSS, and then assessed colitis severity (Fig. 4). The anti-HMGB1 antibodies prevented DSS-induced loss of body weight (Fig. 4A); whereas vehicle-treated controls showed a steady increase in clinical score throughout the observation period, anti-HMGB1 antibodies significantly slowed clinical score progression (Fig. 4B). The anti-HMGB1 antibodies also improved colon histology (Fig. 5A), particularly the disruption or exfoliation of epithelial cells, inflammatory infiltrates and submucosal edema (Fig. 5B).

\section{Discussion}

HMGB1 influences animal models of inflammation such as endotoxemia (14), peritonitis (16), hepatic injury (17) and lung injury (15), where the blockade of HMGB1 with specific antibodies improves survival and inflammation and diminishes circulating levels of pro-inflammatory cytokines. However, little is known regarding the role of HMGB1 in colonic injury.

IL- $1 \beta$ and TNF- $\alpha$ are elevated in experimental colitis and reflect inflammation levels. HMGB1 also increased in the colon, but more slowly than IL- $1 \beta$ and TNF- $\alpha$. Similarly, HMGB1 production in monocytes was induced by IL-1ß and TNF- $\alpha$ as well as by lipopolysaccharide (14), suggesting that HMGB 1 expression in DSS-induced colitis results from enhanced IL-1ß and TNF- $\alpha$ production. HMGB1 also induces the synthesis of cytokines by activated monocytes and 
A

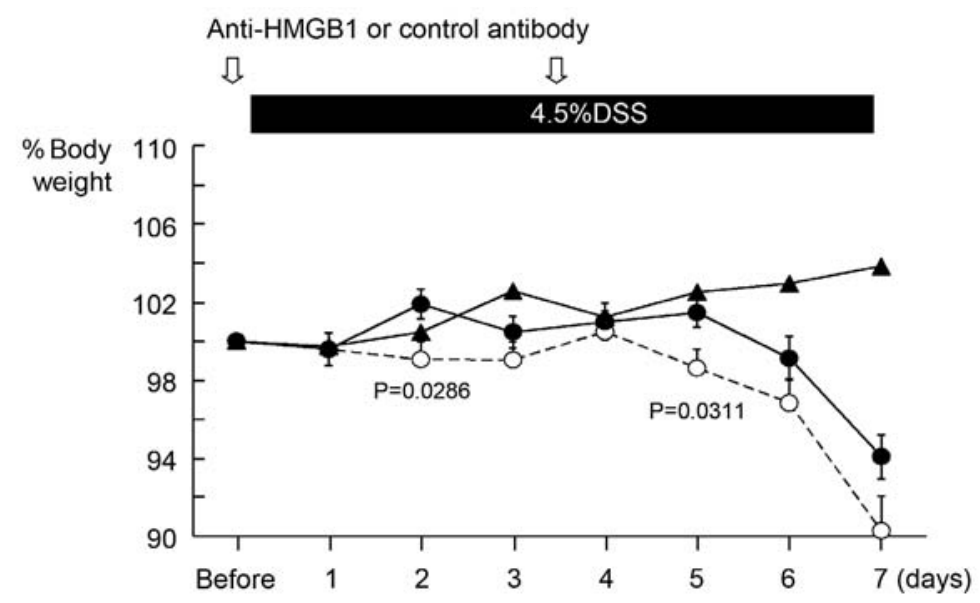

B

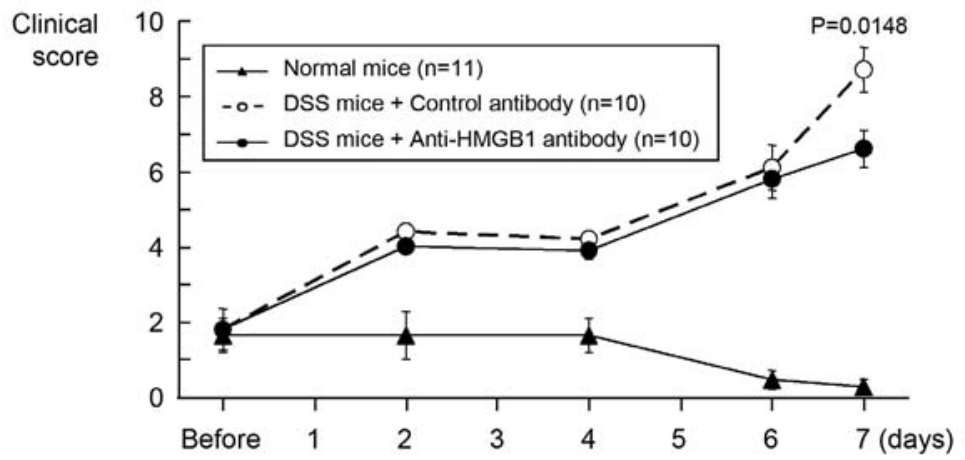

Figure 4. Anti-HMGB1 antibody treatment improves (A) the body weight loss and (B) clinical score during dextran sulfate sodium (DSS)-induced colitis in mice. Two hours before and 3 days after ingesting 4.5\% DSS, mice were injected with either control chicken IgY (Hem+Cont antibody, 200 $\mu \mathrm{g} / \mathrm{mice}, \mathrm{n}=10$ ) or polyclonal chicken IgY anti-HMGB1 antibody $(200 \mu \mathrm{g} /$ mice, $\mathrm{n}=10)$. Data are representative of two independent experiments. P-values vs. control antibody-treated mice are shown.

A

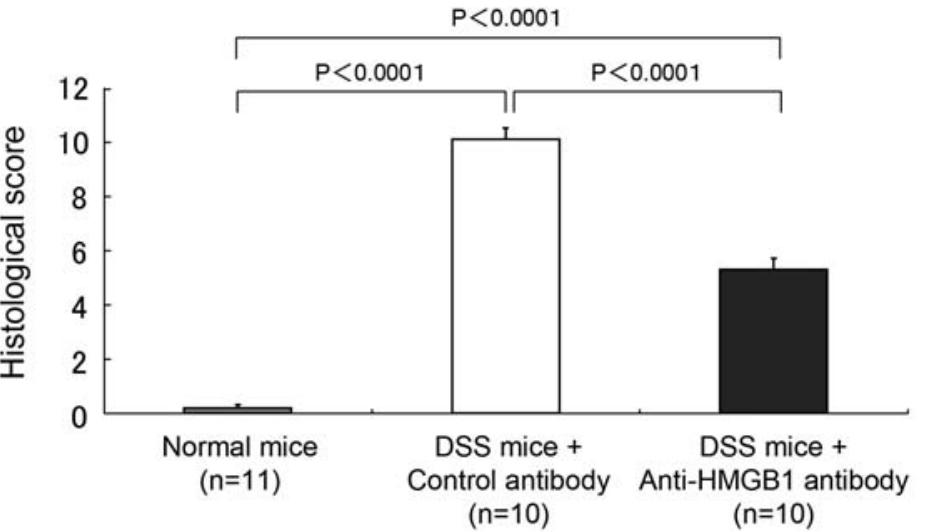

B

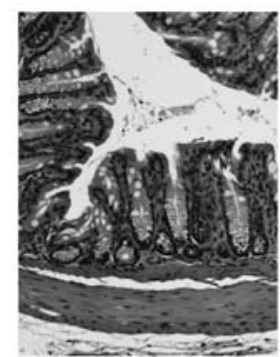

Normal mice

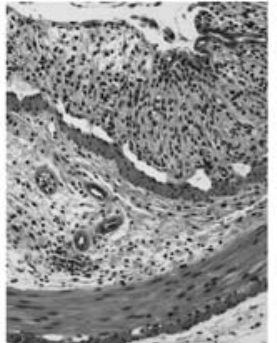

DSS mice + Control antibody

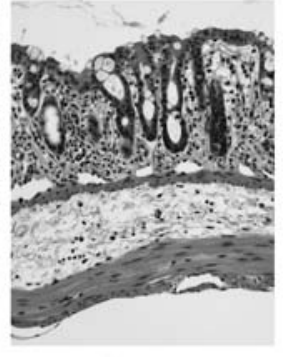

DSS mice +

Anti-HMGB1 antibody

Figure 5. (A) Histological scores in mice treated with anti-HMGB1 antibody $2 \mathrm{~h}$ before and 3 days after ingesting $4.5 \%$ DSS. Mice were injected with either control chicken IgY (Hem+Cont antibody, $200 \mu \mathrm{g} /$ mice, $\mathrm{n}=10)$ or polyclonal chicken IgY anti-HMGB1 antibody ( $200 \mu \mathrm{g} / \mathrm{mice}$, $\mathrm{n}=10)$. The severity of colitis was evaluated 7 days after the initiation of DSS ingestion according to its histological score. (B) Representative H\&E staining of mouse colonic mucosa exposed to DSS. Note that microscopic inflammation was improved by anti-HMGB1 antibodies. Original magnification, x100. 
macrophages (24), potentially leading to a feed-forward inflammatory loop. Animal models of endotoxemia and sepsis show persistent HMGB1 elevation, even after other proinflammatory cytokines can no longer be detected (15). These data point to a role for HMGB1 as a late-acting mediator of inflammation and organ dysfunction.

HMGB1 acts as a cytokine by signaling via RAGE, a transmembrane receptor of the immunoglobulin superfamily (11-13). RAGE staining was barely detectable in the colonic tissues of normal mice, but was elevated in the colonic tissues of the DSS mice. This finding suggests that the up-regulation of RAGE is involved in the colonic injury caused by DSS. Although the role of RAGE in mediating inflammatory responses to HMGB1 requires further investigation, our results suggest that RAGE accumulation accompanies the upregulation of its ligand, HMGB1, associated with DSSinduced colitis.

The results of this study provide compelling evidence for the participation of endogenous HMGB1 in the development of DSS-induced colitis. Specifically, they show that HMGB1 is produced at inflammatory sites, and that its inhibition reduces tissue damage. However, the effect of anti-HMGB1 was not complete, perhaps due to an inadequate dose or the presence of other factors contributing to inflammation. Administration of antibodies against IL-1 (25), TNF- $\alpha$ (26) or the macrophage migration inhibitory factor (27) can ameliorate DSS-induced colitis.

In summary, we found HMGB1 to be up-regulated in DSS-induced colonic lesions, and that an anti-HMGB1 antibody ameliorated tissue damage. This suggests that HMGB1 is an important mediator of colonic inflammation. Therefore, strategies to manipulate HMGB1 expression may constitute a realistic approach to the treatment of colonic inflammation such as human inflammatory bowel disease.

\section{References}

1. Neurath MF and Finotto $S$ : The many roads to inflammatory bowel diseases. Immunity 25: 189-191, 2006.

2. Sartor RB: Mechanisms of disease: pathogenesis of Crohn's disease and ulcerative colitis. Nat Clin Pract Gastroenterol Hepatol 3: 390-407, 2006.

3. Strober W, Fuss I and Mannon P: The fundamental basis of inflammatory bowel disease. J Clin Invest 117: 514-521, 2007.

4. Van Dullemen HM, van Deventer SJ, Hommes DW, Bijl HA, Jansen J, Tytgat GN, et al: Treatment of Crohn's disease with anti-tumor necrosis factor chimeric monoclonal antibody (cA2). Gastroenterology 109: 129-135, 1995.

5. Targan SR, Hanauer SB, van Deventer SJ, Mayer L, Present DH, Braakman T, et al: A short-term study of chimeric monoclonal antibody cA2 to tumor necrosis factor alpha for Crohn's disease. Crohn's disease cA2 study group. N Engl J Med 337: 1029-1035, 1997.

6. Ito H, Takazoe M, Fukuda Y, Hibi T, Kusugami K, Andoh A, et al: A pilot randomized trial of a human anti-interleukin- 6 receptor monoclonal antibody in active Crohn's disease. Gastroenterology 126: 989-996, 2004.

7. Mitsuyama K, Sata M and Rose-John S: Interleukin-6 transsignaling in inflammatory bowel disease. Cytokine Growth Factor Rev 17: 451-461, 2006.
8. Yang $\mathrm{H}$, Wang $\mathrm{H}$ and Tracey $\mathrm{KJ}$ : HMG-1 rediscovered as a cytokine. Shock 15: 2447-2453, 2001.

9. Ulloa L and Messmer D: High-mobility group box 1 (HMGB1) protein: friend and foe. Cytokine Growth Factor Rev 17: 189-201, 2006.

10. Bianchi ME and Manfredi AA: High-mobility group box 1 (HMGB1) protein at the crossroads between innate and adaptive immunity. Immunol Rev 220: 35-46, 2007.

11. Bierhaus A, Humpert PM, Morcos M, Wendt T, Chavakis T, Arnold B, Stern DM and Nawroth PP: Understanding RAGE, the receptor for advanced glycation end products. J Mol Med 83: 876-886, 2005.

12. Schmidt AM, Yan SD, Yan SF and Stern DM: The multiligand receptor RAGE as a progression fac0tor amplifying immune and inflammatory responses. J Clin Invest 108: 949-955, 2001.

13. Bierhaus A, Stern DM and Nawroth PP: RAGE in inflammation: a new therapeutic target? Curr Opin Investig Drugs 7: 985-991, 2006.

14. Wang H, Bloom O, Zhang M, Vishnubhakat JM, Ombrellino M, Che J, Frazier A, Yang H, Ivanova S, Borovikova L, Manogue KR, Faist E, Abraham E, Andersson J, Andersson U, Molina PE, Abumrad NN, Sama A and Tracey KJ: HMG-1 as a late mediator of endotoxin lethality in mice. Science 285: 248-251, 1999.

15. Abraham E, Arcaroli J, Carmody A, Wang H and Tracey KJ: HMG-1 as a mediator of acute lung inflammation. J Immunol 165: 2950-2954, 2000.

16. Yin K, Gribbin E and Wang H: Interferon-gamma inhibition attenuates lethality after cecal ligation and puncture in rats: implication of high mobility group box-1. Shock 24: 396-401, 2005.

17. Tsung A, Sahai R, Tanaka H, Nakao A, Fink MP, Lotze MT, Yang H, Li J, Tracey KJ, Geller DA and Billiar TR: The nuclear factor HMGB1 mediates hepatic injury after murine liver ischemiareperfusion. J Exp Med 201: 1135-1143, 2005.

18. Okayasu I, Hatakeyama S, Yamada M, Ohkusa T, Inagaki Y and Nakaya R: A novel method in the induction of reliable experimental acute and chronic ulcerative colitis in mice. Gastroenterology 98: 694-702, 1990.

19. Elson CO, Sartor RB, Tennyson GS and Riddell RH: Experimental models of inflammatory bowel disease. Gastroenterology 109: 1344-1367, 1995.

20. Cooper HS, Murthy SN, Shah RS and Sedergran DJ: Clinicopathologic study of dextran sulfate sodium experimental murine colitis. Lab Invest 69: 238-249, 1993.

21. Dieleman LA, Ridwan BU, Tennyson GS, Beagley KW, Bucy RP and Elson CO: Dextran sulfate sodium-induced colitis occurs in severe combined immunodeficient mice. Gastroenterology 107: 1643-1652, 1994.

22. Tomoyose M, Mitsuyama K, Ishida H, Toyonaga A and Tanikawa K: Role of interleukin 10 in a murine model of dextran sulfate sodium-induced colitis. Scand J Gastroenterol 33: 435-440, 1998.

23. Yamada S, Inoue K, Yakabe K, Imaizumi H and Maruyama I: High mobility group protein 1 (HMGB1) quantified by ELISA with a monoclonal antibody that does not cross-react with HMGB2. Clin Chem 49: 1535-1537, 2003.

24. Andersson U, Wang H, Palmblad K, Aveberger AC, Bloom O, Erlandsson-Harris H, Janson A, Kokkola R, Zhang M, Yang H and Tracey KJ: High mobility group 1 protein (HMG-1) stimulates proinflammatory cytokine synthesis in human monocytes. J Exp Med 192: 565-570, 2000.

25. Arai $\mathrm{Y}$, Takanashi H, Kitagawa $\mathrm{H}$ and Okayasu I: Involvement of interleukin-1 in the development of ulcerative colitis induced by dextran sulfate sodium in mice. Cytokine 10: 890-896, 1998.

26. Kojouharoff G, Hans W, Obermeier F, Mannel DN, Andus T, Scholmerich J, Gross V and Falk W: Neutralization of tumour necrosis factor (TNF) but not of IL-1 reduces inflammation in chronic dextran sulphate sodium-induced colitis in mice. Clin Exp Immunol 107: 353-358, 1997.

27. Ohkawara T, Nishihira J, Takeda H, Hige S, Kato M, Sugiyama T, Iwanaga T, Nakamura H, Mizue Y and Asaka M: Amelioration of dextran sulfate sodium-induced colitis by anti-macrophage migration inhibitory factor antibody in mice. Gastroenterology 123: 256-270, 2002. 
